\title{
Considerations on the theory of the basis of articulation (I)
}

\author{
Enikő Pál ${ }^{*}$, Francisc Gafton ${ }^{2}$ \\ ${ }^{1}$ Faculty of Economics, Socio-Human Sciences and Engineering, Sapientia University, Piața Libertății 1, 530104 \\ Miercurea Ciuc, Romania \\ ${ }^{2}$ Faculty of Letters, "Alexandru Ioan Cuza" University, Bd. Carol I 11, 700506 Iaşi, Romania
}

\section{Article info}

History:

Received May 19, 2016

Accepted May 24, 2016

Published August 1, 2016

Key words:

diachronic linguistics

linguistic change

basis of articulation

psychological basis

language development

\begin{abstract}
The aim of the present discussion is to observe the various endeavours undertaken in linguistics to discern whether the basis of articulation is a viable and useful concept and-above all-whether or not it reflects reality. Since as far as we know the most fruitful development of this very notion is accomplished within Romanian scientific milieu, by the contributions of A. Philippide and G. Ivănescu, we shall make an attempt to pursue the path which was unfold in the mid $19^{\text {th }}$ century under the influence of the evolutionist perspective and which was followed by the two great theorists of the concept.

In the second part of our study we shall present a brief present-day account of the issue, especially since, subsequent to the two Romanian scholars, Romanian linguistics did not give much attention to this concept, though its existent premises are firm and valuable, i.e. of great aid.
\end{abstract}

\begin{abstract}
"By the manner in which several different people speak French you can recognize that one of them is French by birth, the other one is Romanian, the other German, the other British" "on the lips of Romanians who speak French it is not Romanian language that changes according to French, but rather French alters as per Romanian"
\end{abstract}

(Philippide, 1894)

\section{Preliminaries}

Ever since the beginning of historical linguistics, understanding the processual-historic nature of language, linguists have pursued to discover the underlying principles thereof in order to comprehend its essence. The discovery of the fact that language is in constant motion and evolvement determined linguists to turn their attention and energies to searching the causes of linguistic change, in general, and of phonetic changes, in particular, while the endeavours to unravel these fundamental issues led to various observations and theorizations. Just as in case of any kind of evolution, the empirical finding of change, transformation or evolvement raises at least three main questions: What are the causes of changing?; Why does this process follow certain directions but not others? and Why do major changes come about in certain periods of time but not in others?

The substantial impulse generated within linguistics by W. von Humboldt's thinking, valorised by the contributions of certain scholars like Fr. Bopp, A. Schleicher, H. Osthoff, K. Brugmann, A. Leskien, B. Delbrück, E. Sievers, and W. Scherer, has led to the increase of the empirical-inductive study of language which has been carried out from a historical perspective and in conjunction with the theory of evolution and the philosophical trends of the time. This process was bound to provide solid theoretical grounds to which new reflections and especially compelling material were about to be added, thus establishing a new conception of language evolution with projection onto the causes of linguistic change. The whole

\footnotetext{
*Email address: enikopaldr@gmail.com.
} 
Enikő Pál, Francisc Gafton

nexus of knowledge was subsequently amplified and considered in depth within theoretical syntheses which present the causes of linguistic change from a psychological and biological perspective (Wechssler, 1900; Ginneken, 1933) or within exhaustive treatise which discuss the history of languages and nations from a historical and interactional point of view (Philippide, 1927) or within works which excerpt highly generalized theoretical conclusions, cogently arguing and explaining how the vocal apparatus functions and how the phonetic systems of languages evolve (Grammont, 1933).

\section{Basis of articulation. Problems of the concept and term}

Attempting an inductive approach to the issue, Indo-Europeanists and Romanists sought to discover the causes of language differentiation or the causes which led Vulgar Latin to develop several different physiognomies, i.e. distinct linguistic systems (just like naturalists sought to unravel the origin of species). They took into consideration different causes, which were either intrinsic or extrinsic to language itself, various ways of differentiating the languages, also considering the differences between the stages of the stratum at the time it was imposed, the autochthonous layer which was supplanted by the stratum, as well as the superstrata which affected the languages in question. Even so and beyond these endeavours, certain linguists and philosophers of language sought to uncover the profound causes of linguistic change, observing the phenomena from a strictly linguistic viewpoint and examining the effects occurring on their deep and essential level.

Despite the fact that they were followers of Humboldt and they believed in the idea that language is modelled by the spirit to an extent that it would reflect the spirit of a nation, by means of their conception, Neogrammarians possessed the data necessary to understand that physical factors are actually and effectively entangled in linguistic changes. Moreover, being chiefly interested in the changes which occur on the phonetic level, they understood that these changes are directly determined by physical factors and conditions.

The very first endeavours sought theorization. Holding only empirical data derived from sporadic observations which lacked in scientific control and a linguistic conception in course of formation but mostly based on their philosophical conception of reality, the savants and scholars of the first period made various remarks which were meant to clarify rather speculatively a nebulous concept which could scarcely be explained by the existing scientific methods and instruments. Seeking a concept which would reflect a yet poorly intuited and cogitated reality, nonetheless attempting to clearly comprehend, describe, and demonstrate $^{1}$ it, they created terms like Artikulationsbasis (F. Franke) and Operationsbasis (E. Sievers); besides these two there are others like: Artikulationsweise, Indifferenzlage, Indifferenzzustand, Rubelage, Rubezustand, Normalstand (cf. Kedrova \& Borissoff, 2013). The first series of terms regard the basis of articulation as 'the overall disposition and manoeuvring of the speech organs which are common to all people but peculiar to each nation', whereas the second one defines it as: a) 'the neutral and/or resting position of the articulators'; b) 'the optimal starting position of speech organs [in the articulation of a speech sound]'; c) 'the general direction of movements during speech'; d) 'the nexus of language specific articulatory movements' etc. The first series seems to carry on the Neogrammarians' concern for essences, while the second one seems to turn on the very concrete organs involved in articulation (mainly on the tongue as an articulator) but with special care for both the term ${ }^{2}$ (which, on its own, reflects the static

\footnotetext{
${ }^{1}$ An account of these endeavours is presented in Philippide (1914, 1927); Ivănescu (1980, 1984); see also Borissoff(2011).

${ }^{2}$ Regardless of the degree of delineation and clarity of the concept, the formulas meant to convey it have never been satisfactory enough, the differences between the various conceptions of language and the contrasting views on linguistic change generating different approaches to the very same phenomenon. It is not so much the consequences of terminological diversity-see "basis of articulation" (F. Franke), "basis of operation" (E. Sievers), "the spirit of language" (K. Vossler), "different predispositions" (F. de Saussure), "the genius of language” (B. P. Hasdeu), "preperceptive material” (Philippide)—which bear significance as the differences in its content, i.e. the different comprehension of the concept, which has influenced the greeting discussions, treatments of this issue and those linguistic aspects which it involves in a way or another. For the abundant history of the endeavours seeking to clarify the concept, of the searchings for the most adequate term, and of the numerous
} 
rather than the dynamic aspect) and the integration of the observations into the theoretical framework of reflections on language.

The first direction is mainly theoretical-speculative and it seeks to find the causes, but it is rather lacking in compelling argumentation, whereas the second one seeks to unravel, step by step, the effects, it observes the ways of reality and aims to understand the nature of relations between structure and function. Meant to explain fundamental states and processes of language formation, being, and evolvement, this concept was bound to undergo several elucidatory operations in order to free itself from the dross of subjectivity, speculation, and deductivism, for it to gain the reliability provided by evidence based on observation, experiment, and induction. With the second direction, this alternative route is covered by means of effective use of the concept, for instance in the process of foreign language teaching, also encompassing the data provided by theories on the basis of perception - a field which, by all means, has an extremely vast bibliography.

The linguists influenced by the experimental method of Claude Bernard, by positivism, and by the evolutionary conception recognized the necessity of subduing the research to the empirical and experimental rigour of induction in conjunction with deduction in order to establish theories accordingly and, if necessary, to rectify the philosophical views. They have assumed the obligation for their observations and intuitions expressed in theses to be followed by the correlation of a plethora of observations and data provided by controlled experiments, continued by subduing these results to the processes of logical thinking in order to reach theoretical conclusions validated by both reality and scientific judgements. At the same time, they have understood that science is cumulative and (self-)critical since it selects the ideas demonstrated by means of material evidence and sustained by logical assessment, but it also necessarily and constantly verifies both the already constructed edifice and the elements which tend to put that very construct together. Notwithstanding its arduousness-due to the gap between the dynamics of ideas and the capacity to scientifically demonstrate them, each epoch lacking more or less in methods and instruments necessary to verify the observations and ideas which, needless to say, exceed the ways and means-, this path represents optimally the efficient scientific approach.

\subsection{Basis of articulation - the conformation of the articulators}

Although he sets the spirit at the basis of the existence and evolution of reality, mistaking the causes for the principles and considering that language adapts to the spirit and reflects it, A. Philippide regards the basis of articulation as the genuine and profound cause of linguistic change, on the phonetic level. As he reflects on the basis of articulation and scrutinizes-in terms of structure, function, nexus, and evolvement-the forms of existence of the designated reality, the Romanian linguist nuances his theory, delves deeper into it, and consolidates it. He will come to a coherent conception of the basis of articulation and will seek to establish the notion and its conveying term by defining, explaining, illustrating, and effectively employing them. Initially, A. Philippide conceives the basis of articulation as the conformation of the articulators, including the innate articulatory skills and habits passed down from generation to generation (Philippide, 1914), whereas later on he considers that the basis of articulation evolves being influenced by the environment - in the most general sense of the word — and chiefly by means of language contact, language adapting to the basis of articulation which brings it into phonic being. Therefore, the interaction between the environment and the basis of articulation and the operation of the latter one cause the changes of the basis of articulation which, in its turn, constitutes the cause of linguistic changes on the phonetic level (Philippide, 1927). As noted, the Romanian scholar regards the interaction with the environment as the main factor which determines the physical complex represented by the conformation of the articulators (the basis of articulation).

observations which accompanied this process see Borissoff (2011), Dresher (2016), Dressler (1976), Hinde (1977), Jakobson (1973), Jenkins (1999), Jenner (2001), Koerner (2004), Lenneberg (1971). For the discussion on the options for "basis of articulation" or "articulatory setting" see Borissoff IATEFL; Jenner (2001). 
In A. Philippide's time, B. de Courtenay considered that environment (the physical and geographical conditions) exerts its influence on the organic constitution of the inhabitants, which bears consequences on how their language would be. In its turn, once it has been formed, language influences the constitution of the speech organs and the physiognomy of the individuals, the conjunction of physical conditions and the peculiarity of language development determining languages to tend towards the preponderant use of certain parts of the vocal apparatus or language thereof ${ }^{3}$. Though he did not define the basis of articulation, B. de Courtenay employs the concept considering that it refers to a result common to all members of a community since it derives from the linguistic activity within a social setting and it shows that the skills engaged in it are natural and unconscious, the social practice of imitation preserving the basis of articulation in a stable state. Furthermore, he points out that its variability constitutes the driving force of sound changes, the centripetal force being "weak" (apud Kedrova \& Borissoff, 2013). Although reluctant to certain issues and perspectives, especially when he does not foresee solutions and imagines consequences, F. de Saussure mentiones the influence of the environment but he does so in a rather vague manner. At a time when the issue has already ceased to be discussed in terms of ungrounded statements coming from theoretical reasoning and general conceptions of different authors, G. Ivănescu scrutinizes the factors which determine the dissimilar constitution of the articulators of different nations and he observes, regarding the effects of the climate, that certain manoeuvring peculiarities of the lungs and vocal cords may be explained precisely by climate $^{4}$.

As a matter of fact, as a result of the $17^{\text {th }}$ and $18^{\text {th }}$ centuries' philosophical thinking, especially following Lamarck and Claude Bernard, more and more specialists began to regard the environment as bearing a fundamental and decisive role in the process of evolution in general conception applied in arts as well (H. Taine).

Furthermore, admitting the fact that speech sounds are determined by the elements of the conformation of the instrument which produces them implicitly means to admit that the very same speech sounds are determined by the conformation of the articulators itself. This consistently leads to the fact that any change of the articulators may bring about a change of the sounds produced by the organic complex in question ${ }^{5}$. Since the primary and essential phonetic features of a language are generated by its material basis, the causes of speech sound changes should be sought in the changes of the conformation of the articulators. Once established this interrelation between the nature and disposition of the articulators (the basis of articulation) and the nature of the sounds produced by them and, consequently, between the changes of the basis of articulation and the phonetic changes, what remains to be sought is the complex of factors which contribute to a particular conformation of the articulators and to its changes in certain particular directions.

Designating the state, nature, and disposition of the articulators, the basis of articulation, the element which governs the producing of the perceptible linguistic material, constitutes the direct cause of the functional configuration of a phonetic system at any given time and the cause of sound changes, whereas

\footnotetext{
${ }^{3}$ His evolutionary point of view leads Baudouin de Courtenay to observe that the transition from the state of an animal to the state of a human, endowed with vocal-articulate language, consists in the general exit of imitative sounds from the laryngeal cavity to the buccal cavity (apud Kedrova \& Borissoff, 2013), which may be confirmed by research that shows a direct relation between speech and bipedalism (Falk, 1975, 2009).

4 "In regions with harsh climate, either steppe or polar, laryngeal or glottal sounds have developed" whereas "in regions with mild climate, like the Mediterranean or oceanic ones, laryngeal sounds could not be developed or they have disappeared". In any case, states the author, "the adaptation of the articulators to the physical environment, generally rejected by linguists, cannot be denied” (Ivănescu, 1984). With certain inherent recalibrations, mainly due to the difficulties raised by such an endeavour, these correlations, based on the relation between living beings and their environment, are to be found at both biologists and linguists, though the lack of methodical, common and/or coordinated researches gives way to various shortcomings.

${ }^{5}$ Due to the organic relation between the different compartments of the language system, the changes occurred on the phonetic level may effect, in different degrees but consistently, each subsystem of the language.
} 
the affective-volitional, cultural-spiritual, and cognitive-conceptual complex, i.e. the psychological basis, is responsible for the use and ordering of the produced material. The effects of the first aspect may be observed, predominantly and directly, in the phonetic realm of a language, while the consequences of the second one appear particularly within the lexical, syntactic, and morphological domains. However, just as humans cannot be divided into a purely physical being, on the one hand, and a merely psychological entity, on the other hand, neither can the bases of a language exist or function entirely separated from each other, the relation between them being organic and inextricable. Though it has a biological component, language constitutes a relatively autonomous system, structured in its own way, and the causes of its development cannot be completely separated from its structural-functional (re)sources, but they partially derive from the manner in which the language system itself is ordered and manoeuvred. A. Philippide comprehends that, on the level of its structures and functions, language-a product of social human beings-bears the traces of the doubleness of human condition in which the physical (material) side and the psychological (spiritual) side are intertwined, constituting together what we might call the "biological moment" (Philippide, 1927).

Once admitted the existence of the basis of articulation - the conformation of the articulators which determines how the phonetic system of a language really is and which varies according to the conditions of the physical environment in which different communities live-, what remains to be explained is the complex of conditions in which this very basis, in certain stages of the language development, operates more intensely and faster on language, giving rise to major linguistic changes as opposed to the relatively stable stages of the very same language. Since during the life of every language there are periods of fast linguistic evolvement but also epochs of more or less stability.

It has been relatively early observed and stated that changes may derive from the mere practice of language in the course of several generations, but they also may be due to contacts with other languages. The first case refers to the natural evolution of languages-within the same nation which has not been subjected, by means of mixture or pressure, to any consistent or overwhelming influence from another nation - which operates slowly, producing minor and small-scale changes in the language use passed down from generation to generation. The changes produced in the basis of articulation as a result of the mixture of peoples or by changing the proportion of the human types which form a nation constitute adaptations of the conquerors' language to the basis of articulation of the conquered ones, and they are much more spectacular. In this case, the sudden contact reveals the contrasts and puts them into action; on the one hand, it challenges the existent state, on the other hand, it may unexpectedly show a state which previously has been unfold slowly or hidden from normal evolution. The first kind of process was simply pointed out and implicitly acknowledged as a natural fact by A. Philippide, without further analysis ${ }^{6}$, as he was far more interested in those changes of the basis of articulation which appear as a consequence of the mixture of peoples.

In fact-except for the very first communities and perhaps only for a short period of time, until the mixture of these had become significant, or except for certain contemporary tribes, endangered as they are, isolated from and untouched by what we might call civilisation-, due to the natural-restructuring conditions in which human groups have developed, for many millennia now there has been no such thing as "pure" community. Just like in case of any other domains or objects of cognition, there is a natural tendency of both scientists and laics to regard reality as if it were endowed with purity, symmetry, equilibrium, "perfect" constants, features which are not found in natural objects and processes (no organic matter or celestial object, no organic or unorganic substance, no natural phenomena are "perfect"). Reality always provides "impure" entities. Although, for cognizance, it is easier if judgements set forth from simple features and realities (actually, hypothetical and without any exact correspondent), the reasoning and the

\footnotetext{
${ }^{6}$ For the undeniable merits of Philippide regarding the development of the theory of the basis of articulation and for certain slightly different aspects of it see Ivănescu (1984).
} 
correct results are conditioned by the comprehension and assessment of reality in its actual being. Therefore, not only is it impossible to regard communities as pure entities in any moment of their existence, but we cannot assume any "pure" starting point either. The mere functional existence of an entity of reality - given the fundamentally interactional and dynamic nature of the living matter-makes it a natural rule for it to be a "mixture" with distinct proportions of its constitutive elements (all the more so because among the attributes, conditions, fundamental effects, and sine qua nons of life there are the interaction and adaptability first and foremost to the environment). While comprehending this matter and seeking comfort, it may be imagined that, in their prime and initial state, communities are pure, they shortly, inevitably, and irrevocably would turn to the state of a conglomerate of communities and then to that of a conglomerate of conglomerates and so forth ${ }^{7}$. As a matter of fact, this issue, along with the criticism of the concept 'race', appears with utmost clarity in the criticism made by A. Philippide and addressed to the theory of K. Vossler (Philippide, 1927). On the historical scale, despite their moments of stability, nations are conglomerates of peoples par excellence, just like living cells are symbionts which owe their existence to the symbiosis of several different entities ${ }^{8}$.

On the other hand, the fact that different communities possess different conformations of their articulators and they function differently is related to the distinct conditions of their environment (and to all that almost geometrically derive from this dissimilarity) and it may be observed by means of linguistic analysis. Apart from certain quite subjective remarks of A. Philippide (found in Philippide, 1894, but also in Philippide, 1927), G. Ivănescu makes some empirical observations which demonstrate the relation between certain organic and functional differences and their consequences? .

Furthermore, given the inherent and essential nature of the material, anatomical, and physiological component of a language, it is obvious that the basis of articulation diachronically varies depending on individuals and communities and it constantly exerts its power. On the one hand, since there is no unitary nation, the phonetic system of a nation ought to be considered as

\footnotetext{
${ }^{7}$ Natural cohabitation is by all means and lawlikely assimilatory, since only the fittest (i.e. the most efficient elements capable of survival in the given conditions) are selected. Only those efforts which are consciously oriented towards certain directions may govern cohabitation, either stimulating (in case they refer to elements which would naturally be selected) or inhibiting (when they refer to elements which do not fall under natural selection) the inherent assimilatory processes. This was also the case of the influence of Latin civilisation and language on the conquered ones: a) natural assimilation was set in motion (selecting elements of both the conquerors and the conquered ones); but in conjunction with b) stimulating the process by pressure made in favour of certain elements belonging to the conquerors; and c) preserving certain elements belonging to the conquered ones. Obviously, both in b) and c) it was about elements which would not be selected by nature.

${ }^{8} \mathrm{Cf}$. Wartburg (1962). Recent research show that, due to the dynamics of populations and the interactional setting of civilisations and cultures, there is a significant and inexorable, though relatively "slow" increase of the process of homogenization of populations, civilisations, and cultures (Oliveira et al., 2006).

${ }^{9}$ The disciple of A. Philippide shows that certain vowels are found exclusively or chiefly within certain communities $(\ddot{a}, \ddot{o}$, $\ddot{u}$, mainly characteristic for the Nordics and Phalians or Dalics; $\breve{a}$ and $\hat{\imath}$, specific to the Dinarics and Anatolians as well as to the Mediterraneans of these regions). The very conformation of the articulators would also explain the correspondence between the predisposition to rounded (labialized) velar vowels and lip protrusion characteristic for Dinarics and Mediterraneans or the relation between the producing of the consonants $k$ ' and $g$ ' and a narrower oral cavity - its narrowness resulting from either a more flat and less rounded shape of the palate and superior maxilla or the bigger size of the tongue. The manoeuvring of certain articulators would also explain the emergence or disappearance of $h$ - the presence of a phonic $h$ may be explained by the manner in which the lungs function (by weaker or stronger exhalation) - , while the emergence of the expired explosives may be related to the way in which the vocal cords function, etc. (Ivănescu, 1984). A possible disagreement with the explanations of G. Ivănescu should be followed not by the denial of the whole explanation (which would not bear any causes except for the way in which scientific research is carried out and only in the philosophical and ideological conception of the proponent) but by the genuine search for examples and correlated and correct explanations, and only not finding them at all should lead to rejection. Apart from these, G. Ivănescu makes important remarks on the implicit vowels and timbre, as well as on the resting position of the articulators (Stări și schimbări în legătură cu vocala implicităa, in Ivănescu, 1983, p. 80-86; Timbrul vocalic implicit al consoanelor, in Ivănescu, 1983, p. 87-96; Constituirea unei fonetici care să nu fie fiziologie și acustică, in "Buletinul Institutului de Filologie Română «Alexandru Philippide» din Iași”, V, 1938, p. 55-139, republished in Ivănescu, 1983, p. 219-319).
} 
the result of the selective and mutually-adjusting cumulation of the elements of the systems in contact and of its constituting communities (Philippide, 1927; Ivănescu, 1984). On the other hand, within one and the same community there is no such thing as perfect unity of the basis of articulation either, if regarded in its complex reality. It is only natural that within such community there would be larger or smaller variations of the conformation of the articulators and the articulatory skills (Philippide, 1927; Ivănescu, 1984). While considering nations as conglomerates of communities which constitute them, the approximate unity of a language may be reached by means of levelling, through borrowing, the differences found in different individuals or communities (Philippide, 1927). In other words, the constant cohabitation within a normal (relatively closed) social environment may homogenize the anthropological differences between individuals; the same thing takes place in an open environment too, though with much more difficulties since, in this case, the dynamics is more vivid and the only way to compensate it is to exert a social pressure on the individuals.

On this very basis A. Philippide explains the emergence of Romance languages, which is due first and foremost to the transition of Latin language from the basis of articulation of Latin to the bases of articulation of the conquered peoples, which forced Latin to adapt to these new bases of articulation. In his opinion, this phonetic adaptation began in the very moment when people came into contact and it took place simultaneously with the ethnic mixture: "the dissimilar conformation of the articulators of different Romanized peoples, the lips, the resting position of the tongue, the roof of the mouth, the soft palate, the nose, the vocal cords were bound to produce an immediate deviation from the sounds of Latin, which led to a fast change in these sounds" (Philippide, 1927). This process was subsequently completed once the authority of the Roman state and the prestige of its official language, Latin, came to a halt, i.e. after the Empire was conquered by nomadic people.

Once assumed that the basis of articulation designates 'the conformation of the articulators', as a structure generated by the environmental setting, then determined by and slowly adjusted to both the environmental conditions and the effects of their influence (more or less affected by contact) and that language is a historical and processual result of the manoeuvring of the basis of articulation, under the circumstances mentioned above (being influenced by the physical, biologic, social, and linguistic environment), it is easy to understand that the language of the conquerors is the one which, though imposed as the language of all conquered nations, will bear the influences of the basis of articulation of the conquered, since it is the latter that renders the newly-adopted language according to its possibilities. It is a typical case of assimilation where the conquered does not disappear, only it seems to do so, since the adaptive interaction does not represent a form of annihilation but of mutual modelling. They are the medium which, by means of the structural-functional peculiarities of their vocal apparatus and while adopting the linguistic material brought (imposed) by the conquerors, shall alter the material provided by the latter ones.

This remark is of great significance, though often overlooked, since the confusion of those who regard negatively the basis of articulation derives precisely from the fact that they do not operate this distinction made by A. Philippide, yet without the rigour required for the elucidation of certain possible misunderstandings, and clearly stated by G. Ivănescu.

Regarding the conditions which favoured the manifestation of the basis of articulation of the conquered languages which have become neo-Latin, Ivănescu (1980) has a quite nuanced opinion. He considers that the adaptation of a language to a new basis of articulation cannot indeed take place but in the course of several centuries. Admitting that the basis of articulation of a language cannot manifest itself any timesince there is a time limit for its effects-, the scholar from Iași seeks to unravel those conditions which, at given times, grant their manifestation while others prevent it. According to him, during the Roman 
Empire, the bases of articulation (and the psychological bases) of the nations within the Empire could not be manifested since the social structure was such that could neutralize the differences, imposing all over the place the model propagated by the ruling centre. In this period of Roman reign, characterized by an intense movement of people (transporters of goods, language, civilisation, etc.), the bases of articulation could not be manifested because the intense movement from one region to the other had as one of its effects the spreading over large territories of a common language and common linguistic norms. The transition from exchange economy to natural economy in medieval times (the feudal system in the Occident and the village communities in the Orient), i.e. the transition from an intense urban life to a rural life, partially of feudal order, partially gentilic, is the one that could put obstacles to the imitation of the ideal of language and to the conservation of the common language, since the cessation of close contacts between the regions supplanted the prestigious standard linguistic norm, and "people no longer struggled to speak otherwise than they could" (Ivănescu, 1980). The fall of the Empire and the authority of the Roman state contributed to the emergence of these changes in the fundamental social structures, but the real condition which granted the manifestation of the bases of articulation was not political but economic, and this economic factor consists, in the opinion of G. Ivănescu, of the cessation of the exchange economy and of the intensification of natural economy ${ }^{10}$.

Nevertheless, once admitted the existence and effects of the basis of articulation, the physical means by which it operates and its imperative nature, it is reasonable to assume as well that: a) it affected the Latin spoken by the individuals (still bilinguals or interlinguals; cf. Selinker, 1972) of the conquered territories; b) the changes towards which it oriented could have been obstructed by the centripetal forces of the Roman occupation, however, with no specific and measurable evidence of how these processes took place or to what extent. (Though the conqueror was Latin, to a certain degree, the conquered one was his own language - conquered by the basis of articulation.) The fall of the Empire gives free way to an old reality, i.e. the working of the basis of articulation. What changes after the collapse of the Empire is that: a) the centripetal forces, namely the constant pressure of the Latin environment, disappear; b) the working of the basis of articulation is no longer constrained or prevented from exerting its power moderated by centuries of pressure. However, it is equally reasonable to assume that, after this moment, the working of the basis of articulation could not have been as powerful as in the first period immediately after the Roman conquest. Admitting that the basis of articulation is mutable (as it cannot be immutable), that it has the ability to slowly co-evolve with the phonetic system which it expresses, and that these two may mutually accommodate to each other (even admitting that the basis of articulation is more "rigid", while language is more flexible and supple), it should also be admitted that many elements of the conquerors' system could have adjusted the basis of articulation, its manifestations, subsequent to the cessation of the centripetal forces, modulating only certain aspects of the conquerors' system.

\subsection{Basis of articulation - a set of articulatory skills}

Since as early as his time (but even afterwards, including nowadays) the explanation by the basis of articulation has been employed, but to the term there have been assigned different contents, reflecting the conception of different linguists and being rather convenient than consistent with the theory of the basis of articulation, A. Philippide offers clarifications regarding the relation between the basis of articulation and the skills provided by the use of an indigenous language. Both the criticism of his theory and the

\footnotetext{
${ }^{10}$ In its basics, though without a nuanced contextualization, the idea is found at F. de Saussure who shows that political stability and instability influence language quite differently, political equilibrium stabilizing language (slowing down its movements), while instability increases its variability and dynamics. The temporary steadiness and the relative stability of an idiom may have external causes (the influence of the Court, school, academy, writing), favoured by the social and political equilibrium, while the speed-up of the movements in a language is the consequence (but not solely) of the reversals on this level (Saussure, 1997).
} 
attempts to explain certain concrete situations give him the opportunity to provide important clarifications, pointing out the confusions made by the critics - many of the latter ones being surprising since they sought the scientific criticism of a concept but had no concern for the imperative need to operate with the rigour and precision required by such an endeavour (Philippide, 1927).

One of them is S. Pușcariu, who considers that the manner in which speakers make their utterances may be determined not by the hereditary nature of the basis of articulation but by the customary practice of certain articulatory movements.

In his view, people preserve their old articulatory habits even after a new language is imposed on them. Therefore, since Romanization could not wash away all the traces of the physical and psychological structure of the autochthonous people, it is presumable that in the pronunciation of the Latin language made by indigenous people, accustomed to other articulations and coarticulations, "there would have appeared certain adjustments to the autochthonous articulatory habits" (Puşcariu, 1994). Thus, the specific sounds of each Romance language might be explained by the habits of the indigenous people to utter those particular sounds. Furthermore, S. Pușcariu believes that "when people abandon their mother tongue, they lose their basis of articulation altogether". In this case, based on the observation of a unique and different type of situation (the learning of Romanian language by a minority living among Romanians), he makes reference to the common situation in which children learn the language from their parents (Pușcariu, 1937, 1994).

It seems that S. Puscariu rejects the definition of the basis of articulation as 'the conformation of the articulators', claiming that it refers to 'the articulatory skills', and he also denies the fact that it would be genetically transmitted, i.e. on the physical level (in the Darwinian sense), stating that it is transmitted rather on the functional level (in the Lamarckian way). The explanation given to the different transformations of the Vulgar Latin into the newly emerged Romance languages as they were exclusively due to different articulatory skills is at best lacking, whereas the example of the minority (either bilingual or denationalized) rather denies the existence of the basis of articulation than proves its inexistence, investing skills with actions that cannot be verified ${ }^{11}$. The case of the children (who are monitored by the community and are thoroughly subjected to social pressures) is not even comparable to the case of contact by contest.

A. Philippide draws attention to the possibility of mistaking the changes produced in language by the modifications of the basis of articulation-which is a permanent base-for the ones occurred in the process of adopting a new language. The influence of the autochthonous language consists of preserving certain skills belonging to the abandoned language while accepting another language (which soon shall become the mother tongue $)^{12}$. Thus, according to the Romanian scholar, the influence of an indigenous language on the newly adopted one does not refer to the modifications produced within the adopted language by a different physical and psychological entity but to the direct influence which the abandoned language could have had on the adopted one, that is to say only in this case we are dealing with skills. On the contrary, the influence of the basis of articulation and the psychological basis implies no skills but sound changes of the adopted language in accordance with the particular physical and psychological disposition of the autochthonous speakers. While adopting a new language, speakers may unlearn the sounds they have produced before, adopting the sounds of the new language and perhaps preserving certain skills which they could not free themselves of and which may penetrate into their new language, including in the form of certain sounds of the old language. This is how the influence of the autochthonous language on the adopted one manifests. The basis of articulation, on the contrary, is the one responsible for both the manner in which the sounds of the new language are adopted-adaptating them to the physical constitution of the indigenous speakers-and the nature of the sounds belonging to the mother tongue

\footnotetext{
${ }^{11}$ This kind of attitude is quite frequent when dealing with discarded concepts whose denial is but based on imaginary or less scientific notes, the actual being of an entity in that particular place calling forth constructing another concept whose limits inevitably generate various shortcomings.

${ }^{12} \mathrm{G}$. Ivănescu, in his turn, points out that the influence of the autochthonous language on the language of the conquerors is "anything but the manifestation of the basis of articulation" (Ivănescu, 1980).
} 
out of which some may be preserved in the adopted language as well (Philippide, 1927) ${ }^{13}$.

In conclusion, the basis of articulation refers to an anatomical-physiological reality, namely to the conformation of the articulators, whereas (articulatory) skills or habits refer to the effects of the longstanding manoeuvring and exercising of the articulation base in certain ways (i.e. reflecting a given phonetic system and interacting with it). They are two distinct concepts since they are two distinct realities with two different types of effects, as A. Philippide clearly shows it: "If you truly were to see things from the viewpoint of the basis of articulation and the psychological basis, you would work only on the material provided by the adopted language", since skills or habits refer to the material provided by the conquered language. Thus, examining a debate of $\mathrm{H}$. Schuchardt, who believes that the transition $c t>p t$ should be attributed to the influence of Dacian language on Latin, A. Philippide wonders what H. Schuchardt's reasoning might have been: a) Dacians had had in their language $c t$ which transformed into $p t$, and since the phonetic law had been in force at the time of the contact it continued to be applied, as skill or habit, to the Latin linguistic material as well; or b) Dacians had $c t$ which did not change into $p t$, Latin being added to this material, and it was only afterwards that the phonetic change occurred. This example shows quite indisputably that such criticism was aroused by the theoretical positions adopted by those involved and that the counterexamples did not derive from the thorough examination of a given situation, following the comprehension of the concepts in question, but rather from sustaining certain convictions based on impressions or a general world view.

\subsection{The basis of articulation and borrowing}

Within the same framework, A. Philippide considers it necessary to make another distinction between the changes produced by the basis of articulation and those produced as a result of borrowing (Philippide, $1927)^{14}$. The distinction concerns those situations in which different languages are supposedly related - not necessarily sharing a common descendance but presenting certain essential common features (of belonging to the same geographical, cultural, etc. setting). Acknowledging the chance of arbitrariness in ascribing certain phenomena either to the influence of the indigenous language or to borrowing from the neighbouring languages - which belong to a larger autochthonous base which the language in question also belongs to-, A. Philippide seems less confident in the possibility of their clarification and in establishing certain criteria to distinguish what, in this case, could be regarded as borrowing. Moreover, he cautiously notices that, in these cases, there is no criterion that could serve to distinguish the basis of articulation (and the psychological basis) and the indigenous language heritage, on the one hand, from borrowing, on the other hand. In these circumstances, it may be stated at best that "borrowing is the least likely when the phenomeonon is the most widespread and spread in more details" (Philippide, 1927). For instance, if a phenomenon were spread over in all Balkan languages, it would be reasonable to doubt that it derives from a borrowing having its starting point in one of these languages. On the contrary, if a phenomenon is found solely in a few of these languages, not being present in the majority of the languages, then the given phenomenon may be attributed to borrowing from one language to the other (Philippide, 1927).

\subsection{The basis of articulation - the result of the interaction between the articulators and the articulatory skills}

A. Philippide attributes to the conformation of the articulators a decisive importance, if not exclusive, in determining the phonetic system of a language (Philippide, 1927). Conceiving the issue in a similar way,

\footnotetext{
${ }^{13}$ For the issue of adults' foreign language learning and for the transformations which may occur in this case see Selinker (1972).

${ }^{14}$ By borrowing he means not so much the loans from an autochthonous language to the recently adopted one as the borrowings from neighbouring and contemporary languages (Ivănescu, 1984). In this respect, the following observation is quite eloquent: "When, within a language, there appear certain symbols (words and grammatical forms) which cannot be explained by the adopted language or by onomatopoeia or reflex sounds and for which there is no reason to assume that they could be inherited from the indigenous language but which are found as something common and normal within completely other foreign languages, only then can you say with certainty that those symbols have been borrowed" (Philippide, 1927).
} 
G. Ivănescu makes certain corrections and proposes a few additions. According to him, the basis of articulation also includes the amount of articulatory tendencies which "even though are partially determined by the conformation of the articulators, are inherited and directly influence the language" (Ivănescu, 1980) ${ }^{15}$. In other words, the basis of articulation is a specific conformation of the articulators encompassing their composite action while speaking the mother tongue. This overall arrangement of the speech organs and the articulatory movements which derive from it are necessary for the facile accomplishment of natural utterances in that given language. Therefore, the basis of articulation is the fundamental groundwork (though not exclusive or absolute) which determines the phonetic system of a language and subsequently it is the result of that very functional assembly (Honikman, 1964). Articulatory habits are articulations (concretized as sounds) that are obtained through the natural exercise of a given language during the coarticulation process of the given phonetic system. As time passes by, the articulatory habits are anchored; they become hereditary and may be passed down from generation to generation, eventually constituting the articulatory peculiarity of an individual or community. Both the organs and their products represent dynamic and interactional realities which co-evolve (Honikman, 1964; Oyama, 2015).

\section{Observations on the theory of the basis of articulation and objections to it}

Notwithstanding that some elements of the theory of the basis of articulation could have been adopted and perpetuated by usage, especially regarding the manifestation within Romance languages of the autochthonous pronunciation features, the essence of the theory and many of its aspects and components are yet to be clarified, discussed, and demonstrated. As it occurs in many cases in which attempts are made to establish a scientific theory to explain complex, hierarchical, and intertwined phenomena with a complex and nuanced evolvement, apart from the inherent difficulties of such endeavours, there immediately emerge certain ideological calculations which set in motion unscientific instruments - first and foremost by the very anticipation, prediction, and foreseeing the consequences of a yet unknown phenomenon. This occurs especially when the given theories bear not only scientific implications-at least in the view and from the perspective of those thinkers who set out their reasoning based on postulates or axioms-but also certain collateral, ideological or mentalitary implications (as the theory of evolution, relativity, the quantum theory, etc.). In this case, the more or less vehement objections to the theory almost concur with the spread of the theory itself.

The reluctance to admit the theory of the basis of articulation ${ }^{16}$ is due not only to the fact that different scientists conceive it differently. The first and foremost general reason lies in the fact that they focus on a specified perspective while excluding or minimalizing others, and they wrongly hierarchize principles, research methods, and facts of reality. Therein are all the objective and requisite criticisms since they are concerned with clarifying the essential features, discarding inaccuracies, disengaging the concept from the plethora of intuitions and observations in which it emerged, eventually testing its nature, limits, and operativeness. Their greatest shortcoming is that they usually have as their starting point certain philosophical conceptions which influence the interpretations that govern comprehension. Nevertheless, such observations are valuable as they encourage the enhancement of research in two directions: one is an essential direction which concerns the deciphering of the aspects of a prior reality-which determines the presumed reality which the concept refers to and is connected to-and the aspects regarding its integrated functioning, the effects of its active being and its possible derivatives; the other is a particular direction which refers to the scientific clarification of the concept thus observed and reflected on. The second reason derives from the perspective oriented towards various conceptions and ideas that do not belong

\footnotetext{
${ }^{15} \mathrm{G}$. Ivănescu argues that certain facts like the articulation of $b$ or its absence and the pronunciation of $r$ instead of the intervocalic $s$ respectively cannot be explained by the conformation of the articulators alone but rather by innate articulatory habits (Ivănescu, 1980).

${ }^{16}$ For those researchers who, until the first quarter of the last century, had objected to the basis of articulation, as well as for their arguments see Philippide (1927).
} 
to science per se. Therein converge the objections generated by attitudes common to researchers who fail to acknowledge or understand structuring perspectives of (scientific) reality other than their own or which seem not to incorporate the views and mentalitary desiderates of society, which they adhered to and preach.

As far as they enable research to provide the required scientific answers, both categories of observations may be beneficial. Nonetheless, even before the existence of the concept of the 'basis of articulation' was consolidated, the second type of objections had charged the concept with negative connotations, solely by means of elementary assertions and associating the concept (which should have been understood and clarified first) with other negatively charged notions, stimulating the transfer of attributes from the latter ones to the former one. Thus, the researches which aimed to present the attributes and utility of the concept of the basis of articulation were severely obstructed, but the reiterated and augmented accusations were not accompanied by any specific argument. Paying far too much attention to the intuitive or, at first glance, presumed implications, some of them reject only the term and/or the theory, others distort the issue or avoid it, while others try to understand it in order to find out whether it may be employed at all, whereas a few others seek to construct sophisticated reasonings that would neither discard unscientifically a theory noted for its scientific value nor acknowledge a theory rejected for its supposed ideological flaws, eventually casting it aside (Saussure, 1997; Coșeriu, 1992).

3.1. W. Meyer-Lübke raises the objection that the utterances of Latin made on the particular basis of articulation of the Romanized peoples are almost impossible to prove by facts (Philippide, 1927). In principle, this kind of objection is significant, though-especially in the particular case of Romance languages-the pronunciations of Vulgar Latin may be reconstructed on somewhat reliable grounds. Likewise, there is no question that the indigenous languages exerted a certain influence, as it is obvious that among the sources of the specific phonetic changes of each Romance language there is the autochthonous base governed by the basis of articulation. The Swiss linguist attributes the differences between Romance languages to the different state of Latin at the time it was introduced in distinct regions (of the Empire) and, above all, to the obstacles that prevented the contact between these regions. However, he does not take into account that the different condition of Latin could have been due precisely to the different mixture of peoples and that the ethnic dissimilarities are related to the different bases of articulation, as Philippide (1927) shows it.

3.2. Another criticism addressed to the basis of articulation concerns the ability of an individual, any individual, to pronounce any speech sound and to speak any language, regardless of the conformation of the articulators he or she was born with. F. de Saussure, for instance, claims that the vocal apparatus does not vary from one race to the other, at least not more than it differs from one individual to another, and he gives the example of the African born in France who speaks French just as well as indigenous French people do. (A similar position is adopted by S. Puşcariu who brings into question the case of Germans with French names or the Romanianized Saxons.).

Among all considerations on the theory of the basis of articulation, this one is perhaps the most groundless since it is the only one that does not pertain at all to the domain this theory belongs to. The counter-argument given by F. de Saussure shows that objections should not seek to dispel certain attempts to discover the truth, but they should compete with them in seeking the fact of the matter, since a thought stimulated by a theory, before settling on contradictory positions, should rather seek to unravel how that reality truly is.

The theory of the basis of articulation does not state the immutability or hierarchization of something. On the contrary, recognizing that there is a starting point of a certain nature, with certain characteristics and effects, the theory shows that the basis of articulation is responsible for the allogeneous speaker not being able to articulate as the indigenous one for several generations and that afterwards, when he manages to do so, it will be due to the acquisition of the necessary skills and eventually to the change of the basis 
of articulation. On the one hand, the linguist from Iaşi observes that those phenomena indicated by F. de Saussure and S. Pușcariu may be found at all sorts of languages and people and, above all, that, while staying within the community, as time goes by, foreigners may fully acquire the pronunciation of the people whose language they adopt, but this perfect match of the pronunciation does not necessarily and primarily involve a change of the basis of articulation (Philippide, 1927), since adaptations and skills exist too. Furthermore, A. Philippide regards the basis of articulation as the cause of linguistic change, while the case of a few individuals assimilated into a mass of people whom they live among, or even the case of certain communities that had abandoned their mother tongue and adopted the language of the foreigners who live in permanent contact with them, is completely different from the case of the pre-Roman peoples who adapted Latin (also according) to their own bases of articulation. As a matter of fact, the examples brought into question by F. de Saussure and S. Pușcariu do not show that "the Celts, Iberians, Thracians, Illyrians would not have developed, due to their own bases of articulation and psychological bases, dialectal nuances right from the moment they abandoned their mother tongue and adopted Latin" (Philippide, 1927).

The basis of articulation should not be mistaken for the ability or inability of speakers to pronounce certain sounds per se. In this respect, nothing prevents an African, with a conformation of the articulators of his/her own, from pronouncing the sounds and especially the coarticulations of French, German, etc. just as well as the indigenous speakers do, since different instruments may produce exactly the same sounds (Philippide, 1927). The basis of articulation does not manifest itself only by the possibility or impossibility to pronounce a given sound but also by the preference for the articulation of a given sound or another (Ivănescu, 1984), and its nature is obviously different when inherited by means of the community or acquired by cumulation of characters gained during the lifetime of the individual.

In case of such criticisms, it is interesting, though insignificant, that, on the one hand, F. de Saussure rejects the basis of articulation as a natural given, for it is unacceptable in terms of consequences and hardly explainable on scientific grounds, but, on the other hand, he claims that there exist skills or habits, called by him "different predispositions" (Saussure, 1997), thus actually sustaining the existence of a predetermined fact. Either way, regardless of what he declares, such positions indicate the incomprehension of the fact that the matter is not immutable, that in the course of its evolvement it appears to continuously tend towards equilibrium, and the dominant is neither the element nor the system but rather the environment, broadly speaking. Therefore, the basis of articulation does not imply impossibilities nor hierarchies but temporary constraints and evolvement by means of adaptation to the environment.

Nevertheless, it is noteworthy that, while in the time of F. de Saussure, linguistics advanced various theories on the "superiority" of certain languages over others and it sought to establish certain entirely unscientific and groundless hierarchizations, the criticism formulated by F. de Saussure is excusable and understandable. What cannot be argued with the same considerateness is the perpetuation of this erroneous association ${ }^{17}$.

3.3. Once he considers volition and purpose to be the same and notes that the vocal apparatus is the only physical and material component of language, K. Vossler claims that the cause of sound changes should be sought within human psyche, in the psychological basis by which he means, first and foremost, the cognitive representations and the affect that accompanies these representations. According to K. Vossler, the mental representations of sounds are never the same, they always change and vary, so that the qualitative changes produced in the representation of a sound occur with no intervention of the occasional physical sounds but merely through a qualitative leap made within the mind, i.e. they take place solely by the fact that

\footnotetext{
${ }^{17}$ This leads to another aspect which is important to the development of science and which has often been observed and noted but more frequently has been ignored. Since they are determined by environmental factors in the broad sense, the conceptions may satisfy certain concrete and actual needs and sometimes they may serve as guidelines for future research and for the development of subsequent concepts. Notwithstanding that these results may often be erroneous, their spatio-temporally, circumstantially, etc. marked character necessarily makes them to become perishable, fact that research ought to observe and act accordingly by regular verifications, reconsiderations, and adaptations to the new realities.
} 
the representation itself changes its nature, and it is this nature changed in the consciousness of speakers that is copied or rendered by the occasional sound. Furthermore, K. Vossler considers that changes are produced more or less by a myriad of concurring elements which, as a matter of fact, linguists have always taken into account (beginning with the momentary disposition, turning to the phases in which language is passed down from one generation to another and concluding with fashion) (Philippide, 1927).

Regarding the dismissal of the physical factor, A. Philippide counters the idealism of Vossler by a most felicitous riposte: "Why cannot the thing that produces sounds change them as well?" (Philippide, 1927), whereas regarding the manner in which representations and concepts are formed, A. Philippide notes: "just as I cannot acquire the cognizance of wolf and the cognizance of yellow until I have seen the wolf and the yellow within the physical world, neither can I acquire the cognizance of $\breve{a}$ in the word tacere until I have perceived $\breve{a}$ within the physical world, as a physical sound of the occasional speech" (Philippide, 1927). In other words, the psyche cannot create an objectual and/or acoustic reality, neither can it turn into another, it only may replace a representation of a reality existent in the material world with another representation. Since, if we admitted that a representation of a sound may emerge without it had existed in speech, it would be impossible to show how could that representation give instructions to the articulators on how to produce the corresponding (changed) sounds in the occasional speech (Philippide, 1927). By doing so, the linguist from Iași adopts the Peripatetic axiom (Nibil est in intellectu quod non prius fuerit in sensu 'Nothing is in the intellect that was not first in the senses') and joins empiricism, which has a long philosophical tradition, partially adopted by natural sciences, after R. Bacon programmatically and systematically placed it at the base of scientific research method. The conception is widely represented in contemporary linguistics by A. Schleicher and M. Müller, among others.

As a matter of fact, the role of the affect in sound changes raises several questions. It is probably true that the very first speech sounds came into being as a result of reflex movements stimulated by emotions, so that a certain affective state precedes occasional speech, this fact constituting the reason for which the instrument necessary for sound reproduction has been employed and modelled, being operated in a particular way (Philippide, 1927). This "primitive proceeding", in which emotion creates the instrument and sounds, can no longer operate-except for certain cases $^{18}$ - within an already formed language that changes because emotion stimulates only the reproduction of the already existent instrument and it can only modify it a bit, in the sense that "the feelings of excitement close more and more the sounds, while those of depression open them wider or make the vocal cords cease their vibration" (Philippide, 1927). On the other hand, sentiment may have certain effects on how the instrument is manoeuvred, in the sense that it stimulates variability in the instrument's manoeuvring time (tempo), in the amplitude of its vibrations (expiratory accent) and in the number of vibrations within a given amount of time (melodic accent), which determine whether sounds are more or less energetic, whether they have more or less power to stay unchanged. But the sentiment does not create the accents and duration per se, since they are inherent in sounds by the mere act of being produced, thus existing independently of the sentiment as well. What may be attributed to the affect is solely the variability of accents and duration which, however, has no consistency or persistence in tending towards the same direction (Philippide, 1927). When there is no persistence in tending towards the same direction, there is no actual sound change (i.e. timbre change) because the differences revolve around the same point and neutralize each other. Under such circumstances, the cognitive representations and the affective complex, i.e. what constitutes broadly the psychological basis of K. Vossler, accompany speech sounds, but they do not have the necessary power to change them (Philippide, 1927) ${ }^{19}$.

\footnotetext{
${ }^{18}$ Certain remnants of it may be found in onomatopoeic words and in the ongoing process of creating new interjections.

${ }^{19}$ The discussion on the directions and the persistence of variations is extremely complex and it is well represented in natural sciences, especially after the emergence of the theory of evolution. We shall discuss this issue in the second part of our study.
} 
"Psychological basis" is a term and concept employed by A. Philippide, who gives them a broader interpretation than K. Vossler does, since by psychological basis the Romanian linguist means "the nature of the psyche regarded as intellect and sentiment" (Philippide, 1927), in other words the human soul in its entirety, including the intellect (cognition, knowledge, and culture), the affects, and volition altogether ${ }^{20}$.

Nevertheless, the criticism formulated by K. Vossler essentially differs from all the other previously discussed objections. Unlike the others, the German linguist does not take into account causes of ideological nature, but his starting point is rather a philosophical world view. His error is solely due to the reductionism and exclusivism he practices-based on his philosophical conception-, by means of which he reduces everything to the psychological factor, which he absolutizes, and rules out the physical factor. In fact, language does not emerge nor is constituted with a specific purpose or as a result of a purpose, but it is rather a historical product of the existence and functioning of the human being within a social setting. While evolving, systematizing, and specializing itself language ends up being cognizant and it finds its purposes, but these purposes do not change radically its essence, just like a living being cannot modify its nucleic acids which it derives from, just like natural linguistic signs, though charged with psychosocial, cognitive, even self-reflexive strata, do not lose their natural fundaments.

In order to be perceived both within and outside of cognition, language, as an instrument of communicating experiences, knowledge, states, ideas, etc., has to employ a material, acoustic sign system produced by the movement of the articulators ${ }^{21}$. Since the nature of sounds (that are physical realities derived from articulations) are determined by the nature and manoeuvring of the speech organs, it is quite understandable that sound changes are also essentially material and that they are imposed on the psyche after they have been physically produced. The conscience of the speaker perceives and interprets them. Even though it was admitted that changes have their starting point in an impulse of the psyche, whatever that might be, conscience would not be able to operate with something that has not yet been produced physically. In other words, any base is material; the psychological factor may exert certain influences, but it cannot determine the material matter in absolute terms. Therefore, language development cannot be regarded as isolated from its material base or physical conditions, just like it cannot be subsequently detached from its psychological and spiritual base and generally from the speaker or the social and historical setting in which communication and cognition through language is produced. A. Philippide believes that the psychological basis plays an important role in the configuration of the particular physiognomy of a language, but he also shows that the individualizing aspect of a language is, above all, its phonetic system. The psychological (affective, temperamental) and/or cognitive and spiritual conditions (thought system, world view) are not always radically different from one nation to another and, when there are indisputable differences, they have apparent repercussions on how the lexis, morphology, and syntax of a language is structured but not on the phonetic system of the language in question (Philippide, 1927).

\section{Partial conclusions}

While the fact that language is conditioned by psychosocial factors had never been so severely disputed by linguists - not even when language was studied exclusively by means of its linguistic structures, as structuralists generally do-, the fact that language is determined by physical factors (too), by the nature of the speech organs and their manoeuvring, was often looked upon with disapproval or, in any event, it was regarded by many researchers as insignificant or secondary to other factors.

Nevertheless, the existence of a basis of articulation which governs the nature of a language and its

\footnotetext{
${ }^{20}$ According to the conception of the Romanian linguist, the psychological basis combines ethnic specific elements with psychological, cultural components, also including universal and formal elements, namely the act of thinking itself which is common to all mankind, since it is the same in all times and at all peoples, and which might be called spiritual basis (Ivănescu, 1980, 1984).

${ }^{21}$ In fact, it is quite the opposite: those physical-affective movements came to be the communication system; they precede "the emergence of language".
} 
phonetic changes is clearly evident when we observe it on the overall level, in its composite features. Pursuing it in details and presenting it in descriptions seem to be quite difficult though. Philippide himself, who has the merit of developing this theory, not sufficiently clarified by any scholar before him, acknowledges the fact that the basis of articulation fails to explain the phonetic changes in all their complexity, fact also reflected by the need for terminological clarifications or specifications regarding the content of the terms employed.

\section{Bibliography}

Anderson, S.R. (1985). Phonology in the Twentieth Century. Theories of Rules and Theories of Representations, The University of Chicago Press, Chicago.

Borissof, C.L. (2011). Basis of articulation and articulatory setting in pronunciation teaching: Focusing on English and Russian, dizertație master, Universitatea din Londra, [online].

Borissoff IATEFL = Borissoff, C., Basis of Articulation or Articulatory Setting?, IATEFL Pronunciation Special Interest Group Newsletter Issue 46, [online].

Coșeriu, E. (1992). Linguistic changes does not exist?, traducere de Emma Tămâianu, în „Cercetări de lingvistică”, anul XXXVII, nr. 1, p. 9-20.

Dessalles, J-L. (2007). Why We Talk. The Evolutionary Origins of Language, Oxford University Press, Oxford.

Dorogovtsev, S.N. \& Mendes, J.F.F. (2001). Language as an Evolving Word Web, în „Proceedings of The Royal Society B. Biological Sciences", vol. 268, nr. 1485, p. 2603, arXiv, Crossref.

Drachman, G. (1973). Phonology and the basis of articulation, în „Sprache”, vol. 19, p. 1-19.

Dresher, B.E. (2016). Contrast in Phonology, 1867-1967: History and Development, în „Annual Review of Linguistics”, vol. 2, p. 53-73, Crossref.

Dressler, W. (1976). Fonologia naturale e cambio linguistico, în Simone, R., Vignuzzi, U. \& Ruggiero, G. (eds), Studi di fonetica e fonologia. Atti del convegno internazionale di studi, Padova 1 e 2 ottobre, 1973, Bulzoni, Roma, p. 273-283.

Falk, D. (1975). Comparative Anatomy of the Larynx in Man and the Chimpanzee: Implications for Language in Neanderthal, în „American Journal of Physical Anthropology”, vol. 43, nr. 1, p. 123-132, Crossref.

Falk, D. (2009). Finding our Tongues: Mothers, Infants and the Origins of Language, Basic Books, New York.

Francescato, G. (1968). Speech perception and the „basis of articulation”, în „Folia Linguistica”, vol. 2, nr. 3-4, p. 176-182, Crossref.

Gick, B., Wilson, I., Koch, K. \& Cook, C. (2004). Language-Specific Articulatory Settings: Evidence from Inter-Utterance Rest Position, în „Phonetica”, vol. 61, nr. 4, p. 220-233, [online], Crossref.

Ginneken, J. van (1933). La biologie de la base d'articulation, în „Psychologie du Langage”, Librairie Félix Alcan, Paris, p. 266320 , [online].

Grammont, M. (1933). Traîté de phonétique, Ch. Delgrave, Paris.

Guion, S. G. (2003). The Vowel Systems of Quichua-Spanish Bilinguals. Age of Acquisition Effects on the Mutual Influence of the First and Second languages, în „Fonetica”, vol. 60, nr. 2, p. 98-128, Crossref.

Hinde, R.A. (1977). Le basi biologiche del comportamento sociale umano, Zanichelli, Bologna.

Honikman, B. (1964). Articulatory Settings, în Abercrombie, D., Fry, D. B., MacCarthy, P. A. D., Scott, N.C. \& Trim, J.L.M. (eds), In Honour of Daniel Jones, Longman, Londra, p. 73-84, [online].

Ivănescu, G. (1972). Storia delle parlate popolari e storia delle lingue letterarie, în „Philologica”, vol. II, p. 5-25.

Ivănescu, G. (1980). Istoria limbii române (în special Preliminarii), Editura Junimea, Iași.

Ivănescu, G. (1983). Lingvistică generală și românească, ediție de Vasile Șerban și Vasile D. Țâra, Editura Facla, Timișoara.

Ivănescu, G. (1984). Alexandru Philippide - Teoretician al limbajului, studiu introductiv la Philippide (1984), p. IX-XLVI.

Ivănescu, G. (1998). Studii de istoria limbii române literare, ediție îngrijită și prefaţă de Al. Andriescu, Editura Junimea, Iași.

Jakobson, R. (1973). Main Trends in the Science of Language, Allen \& Unwin, London.

Jenkins, L. (1999). Biolinguistics. Exploring the Biology of language, Cambridge University Press, Cambridge.

Jenner, B. (2001). Genealogies of Articulatory Settings: Genealogies of an idea, în „Historiographia Linguistica”, vol. 28, nr. 1-2, p. 121-141, Crossref.

Kedrova, G. \& Borissoff, C.L. (2013). The Concept of 'Basis of Articulation' in Russia in the First Half of the 20th Century, in „Historiographia Linguistica”, vol. 40, nr. 1, p. 151-197, Crossref.

Kellog, V.L. (1907). Darwinism to-day, H. Holt and Company, New York, [online].

Koerner, E. F. K. (2004). Essays in the History of Linguistics, John Benjamins, Amsterdam - Philadelphia, Crossref.

Kovács, F. (1971). Linguistic Structures and Linguistic Laws, Akadémiai Kiadó, Budapest.

Lenneberg, E. H. (1971). Fondamente biologici del linguaggio, Universale Bollati Boringhieri, Torino.

Lieberman, Ph. (1984). The Biology and Evolution of Language, Harvardy University Press, Cambridge, MA.

Lieberman, Ph. (2006). Toward an Evolutionary Biology of Language, Harvard University Press, Cambridge, MA. 
Lowie, W.M. \& Bultena, S. (2007). Articulatory settings and the dynamics of second language speech production, în Maidman, J. (ed.), „Proceedings of the PTLC 2007 Phonetics Teaching \& Learning Conference, London, UCL, aug. 24-26, 2007”, Londra, [online].

MacNeilage P. (2008). The Origin of Speech, Oxford University Press, Oxford.

Meillet, A. (1925). La méthode comparative en linguistique historique, H. Aschehoug, Oslo.

Mennen, I., Scobbie, M.J., Leeuw, E. de, Schaeffler, S. \& Schaeffler, F. (2010). Measuring language-specific phonetic settings, în „Second Language Research”, vol. 26, nr. 1, p. 13-41, [online], Crossref.

Oliveira, V.M. de, Gomes, M.A.F. \& Tsang, I. R. (2006). Theoretical model for the evolution of the linguistic diversity, în „Physica A: Statistical Mechanics and its Applications”, vol. 361, nr. 1, p. 361-370, Crossref.

Osborn, H.F. (2012). Darwin's Theory of Evolution by the Selection of Minor Saltations, în „The American Naturalist”, vol. XLVI, nr. 542, 1 febr., p. 76-82, Crossref.

Oyama, S. (2015). Sustainable Development: Living with Systems, în Earth, Life, and System: Evolution and Ecology On a Gaian Planet, Fordham University, New York, p. 203-224.

Philippide, A. (1894). Istoria limbii române, vol. I, Principii de istoria limbii, Tipografia Națională, Iași.

Philippide, A. (1914). Introducere în știința limbii (reprodus în Philippide, 1984, p. 239-284).

Philippide, A. (1927). Originea romînilor, vol. II, Ce spun limbile română și albaneză, Tipografia „Viața Românească”, Iași, \$268, nota, p. 246-309; s-a consultat și ediția din 2016, ed. Roxana Vieru.

Philippide, A. (1984). Opere alese. Teoria limbii, editate de G. Ivănescu și Carmen-Gabriela Pamfil, cu un studiu introductiv și comentarii de G. Ivănescu, Editura Academiei, București; s-a consultat și cap. XII, Învăţăminte trase din istoria sunetelor limbii române pentru originea Romînilor, p. 341-398.

Pușcariu, S. (1937). Études de linguistique roumaine, Georg Olms Verlag, Cluj - București.

Pușcariu, S. (1976). Limba română, vol. I, Privire generală, ediție, note, bibliografie, de Magdalena Vulpe și Ilie Dan, Editura Academiei, București.

Pușcariu, S. (1994). Limba română, vol. II, Rostirea, ediție îngrijită de Magdalena Vulpe, Editura Academiei, București.

Saussure, F. de (1997). Corso di linguistica generale, Introduzione, traduzione e commento di Tullio Di Mauro, Laterza, Roma - Bari.

Selinker, L. (1972). Interlanguage, în „International Review of Applied Linguistics”, vol. 10, nr. 1-4, p. 209-232, Crossref.

Thomason, S. G. \& Kaufman, T. (1988). Language Contact, Creolisation, and Genetic Linguistics, University of California Press, Berkeley, CA.

Trout, J.D. (2001). The biological basis of speech: What to infer from talking to the animals, în „Psychological Review”, vol. 108, nr. 3, p. 523-549, Crossref

Vargha-Khadem, F., Watkins, K.E., Price, K.J., Ashburner, J., Alcock, K.J., Connelly, A., Franckowiak, R.S.J., Friston, K.J., Pembrey, M.E., Mîshkin, M., Gadian, D. G. \& Passingham, R.E. (1998). Neural basis of an inherited speech and language disorder, „Proceedings of the National Acadademy of Sciences of the USA”, vol. 95, p. 12695-12700, Crossref.

Wartburg, W. von (1962). Problémes et méthodes de la linguistique, Presses Universitaires de France, Paris.

Wechssler, E. (1900). Gibt es Lautgesetze?, Niemeyer, Halle.

Wilson I. \& Gick B. (2006). Articulatory Settings of French \& English Monolinguals \& Bilinguals, „The Journal of the Acoustical Society of America”, vol. 120, nr. 5, p. 3295, [online], Crossref. 